\title{
Characterization of a calcium porter of Streptococcus pneumoniae involved in calcium regulation of growth and competence
}

\author{
Marie-Claude Trombe* \\ Centre de Recherches de Biochimie et Génétique Cellularies du CNRS et Université Paul Sabatier, \\ 118 route de Narbonne, 31062 Toulouse Cédex, France
}

(Received 14 July 1992; revised 18 September 1992; accepted 23 October 1992)

\begin{abstract}
It is shown that Streptococcus pneumoniae possesses a $\mathrm{Ca}^{2+}$ transporter, sensitive to the amiloride derivative $\mathbf{2}^{\prime}, \mathbf{4}^{\prime}$ dimethylbenzamil (DMB), which is essential for grown at high $\mathrm{Ca}^{2+}$-concentrations, and which mediates the triggering by $\mathrm{Ca}^{2+}$ of competence for genetic transformation in the exponential phase and autolysis in the late exponential phase. DMB inhibited both $\mathrm{Ca}^{2+}$ transport and the $\mathrm{Ca}^{2+}$ response. Kinetic analysis of ${ }^{45} \mathrm{Ca}^{2+}$ transport in ATP-depleted $S$. pneumoniae revealed an electrogenic influx sensitive to DMB. This transport was cooperative with respect to $\mathrm{Ca}^{2+}$ concentration, and exhibited a Hill coefficient $(\mathrm{nH})$ of 2 . In bacteria pre-loaded with ${ }^{45} \mathrm{Ca}^{2+}$, a DMB-sensitive efflux could be triggered by an imposed $\mathrm{Na}^{+}$gradient. The efflux kinetics showed the same cooperativity profile as $\mathrm{Ca}^{2+}$ concentration and a similar $\mathrm{nH}$ value to that of influx, suggesting a possible $\mathrm{Na}^{+} / \mathrm{Ca}^{2+}$ antiport. Cooperativity of transport was lowered $(\mathrm{nH}=1)$ by a mutation that confers resistance to DMB and abolishes the $\mathrm{Ca}^{2+}$ response. These results demonstrate that DMB-sensitive $\mathrm{Ca}^{2+}$ transport is essential for growth and competence regulation. The role of the DMB-sensitive porter involved in $\mathrm{Ca}^{2+}$ circulation and in $\mathrm{Ca}^{2+}$ homeostasis and its possible regulation by competence factor are discussed.
\end{abstract}

\section{Introduction}

The roles of $\mathrm{Ca}^{2+}$ in eukaryotes, including yeast, are diverse and important, ranging from activation of enzymes to hormone release and cell cycle control. Both $\mathrm{Ca}^{2+}$-porters and $\mathrm{Ca}^{2+}$-binding proteins, (calmodulins) have been described (for reviews see Campbell, 1983; Carafoli, 1987, 1988). In prokaryotes, $\mathrm{Ca}^{2+}$ is also involved in various processes (for reviews, see Norris et al., 1991; Onek \& Smith, 1992), and calmodulin-like proteins have been characterized in several species (Inouye et al., 1983; Fry et al., 1983; Swan et al., 1987, 1989; Falah et al., 1988). $\mathrm{Ca}^{2+}$-transporters including pumps and channels, have been identified (Kobayashi et al., 1978; Vrij et al., 1985; Ambudkar et al., 1986). So far, the role played by $\mathrm{Ca}^{2+}$ in bacteria is poorly understood. It is reported that $\mathrm{Ca}^{2+}$ activates autophosphorylation of the heat-shock protein, DnaK, in Escherichia coli (Cegielska \& Georgopoulos, 1989), and that it stimulates expression of the virulence factor haemolysin in Actinobacillus pleuropneumoniae (Frey \& Nicolet, 1988).

*Tel. 61335971 ; fax 61335886.

Abbreviations: CF, competence factor; DMB, 2',4'-dimethylbenzamil; HMA, 5-( $N, N^{\prime}$-hexamethylene)amiloride.
In Streptococcus pneumoniae, $\mathrm{Ca}^{2+}$ is an obligatory cation for growth. However, high $\mathrm{Ca}^{2+}(1 \mathrm{mM})$ triggers, via an exported protein (competence factor, $\mathrm{CF}$ ), the induction of competence for genetic transformation in exponentially growing cultures and lysis in early stationary phase. DNA uptake at competence prevents lysis in early stationary phase, and it has been proposed that DNA transport constitutes a homeostatic response to elevated $\mathrm{Ca}^{2+}$ levels (Trombe et al., 1992). On the other hand, autolysis, dependent on the activity of the $N$ acetylmuramidase encoded by lyt $A$ (Sanchez-Puelles $e t$ al., 1986), is involved in the pathogenicity of smooth derivatives of Streptococcus pneumoniae (Berry et al., 1989). Interestingly, competence induction and culture lysis are prevented by the $\mathrm{Ca}^{2+}$-channel inhibitor $2^{\prime}, 4^{\prime}$ dimethylbenzamil (DMB) (Trombe et al., 1992). In the present report, the kinetic parameters of the DMBsensitive component of calcium transport have been established, both in the wild-type strain and in a DMBresistant mutant of $S$. pneumoniae, and correlated with the $\mathrm{Ca}^{2+}$ response.

\section{Methods}

Strains. The RX derivative of Streptococcus pneumoniae, strain Cp1015, bearing the strRI mutation, was used as the standard wildtype strain (Morrison et al., 1984). The required mutations were 
introduced into the wild-type background by genetic transformation using DNA from the mutant strains. Two rounds of transformation with non-saturating levels of DNA were performed to reduce the chance of multiple gene transfer. The mutation in the com locus of strain Cp1322 was introduced with DNA from strain omega 22, a competence-defective mutant selected after insertional mutagenesis (Morrison et al., 1984). The relevant phenotypes of Cp1322 are its inability to produce CF (Morrison et al., 1984) and its resistance to $\mathrm{Ca}^{2+}$-induced lysis (Trombe et al., 1992).

Screening of Cpl015 for spontaneous mutants resistant to DMB was done on plates containing $15 \mu \mathrm{g} \mathrm{DMB} \mathrm{ml}{ }^{-1}$. Their frequency in a culture was between $10^{-5}$ and $10^{-4}$. After characterization of their natural transformability, clones altered for competence regulation were selected. Mutations conferring DMB resistance were transferred to the wild-type background by genetic transformation. Bacteria transformed to $\mathrm{DMB}$ resistance (DMB ${ }^{\mathrm{R}}$ transformants) were selected on plates containing $15 \mu \mathrm{g} \mathrm{DMB} \mathrm{ml}{ }^{-1}$, as described previously (Trombe et al., 1992). Strain Cp2200 was taken as a representative of pleiotropic mutants in which the $\mathrm{DMB}^{\mathrm{R}}$ phenotype was associated with an alteration of competence regulation.

Specific materials. The source of $\left[{ }^{3} \mathrm{H}\right] \mathrm{DNA}$ was the thymidineauxotrophic strain R119, which also carries the rif-32 mutation (Tiraby \& Fox, 1973). Amilorides were from Merck Sharp \& Dohme, USA, and were provided by Dr E. J. Cragoe. DMB was prepared specifically for this study. Nutrients used for growth media were from Difco. ${ }^{45} \mathrm{Ca}^{2+}$ was from CEA, France. Luciferase-luciferin and ATP were from Sigma.

Growth and competence induction. Growth conditions and media were identical for the wild-type and mutant strains, as described previously (Clavé et al., 1987). Briefly, stock cultures were grown at $\mathrm{pH} 7.5$ in a complex medium containing $\left(\mathrm{g} \mathrm{l}^{-1}\right): \mathrm{NaCl}, 5$; yeast extract, 1 ; tryptone, 5; enzymic casein hydrolysate, 10 ; glucose, $2 ; \mathrm{K}_{2} \mathrm{HPO}_{4}, 3$. This medium contained $120 \mathrm{~mm}-\mathrm{Na}^{+}$and $0.2 \mathrm{~mm}-\mathrm{Ca}^{2+}$ as measured by atomic absorption spectrometry. Growth curves were measured and autolysis tests were done as described previously (Trombe et al., 1992). For transport experiments, a culture frozen at an $O D_{550}$ of 0.4 was thawed, centrifuged at $4{ }^{\circ} \mathrm{C}$ and washed with uptake medium; the pellet was kept at $4{ }^{\circ} \mathrm{C}$ before use (5-30 min). Such bacteria had an ATP pool of $3 \mu \mathrm{M}$ compared with $0.25 \pm 0.05 \mathrm{~mm}$ in exponentially growing bacteria. They were taken as ATP-depleted cells. ATP measurements were made using a luciferase-luciferin assay as described by Lopez $e t$ al. (1989). The intracellular $\mathrm{Na}^{+}$content was estimated at $85 \pm 5 \mathrm{~mm}$ by atomic absorption spectrometry.

Transport measurements. In general, values for uptake at $15 \mathrm{~s}\left(V_{15 \mathrm{~s}}\right)$ were taken to approximate to the initial rate of transport, and these values are referred to as initial rates throughout the paper. Kinetic measurements $(0-60 \mathrm{~s})$ were made to verify the linearity of the response during this interval. $\mathrm{Ca}^{2+}$ transport was assayed using the radioactive isotope ${ }^{45} \mathrm{Ca}^{2+}$. In streptococci, ion pumps, including a $\mathrm{Ca}^{2+}$-pump, are well known (for reviews, see Heefner, 1982; Rosen, 1987). The $\mathrm{Ca}^{2+}$ pump expels $\mathrm{Ca}^{2+}$ from the cells. Therefore, ATP-depleted bacteria were used to avoid interference between the activities of these putative pumps and of the porter being studied. ATP-depleted bacteria were suspended in the appropriate uptake medium at room temperature to give a suspension of $\mathrm{OD}_{550}$ between 2 and $5 . \mathrm{A} \mathrm{Ca}^{2+}$ gradient (in < out) was imposed by addition of $\mathrm{a}^{45} \mathrm{Ca}^{2+}$ solution and $0.1 \mathrm{ml}$ samples were filtered at intervals through $0.45 \mu \mathrm{m}$ Gelman Metricel membranes. After three washes with medium containing $0.5 \mathrm{mg} \mathrm{CaCl}_{2} \mathrm{ml}^{-1}$, the radioactivity retained on the filters was quantified by liquid scintillation as previously described (Trombe et al., 1984). It was verified that $\mathrm{Ca}^{2+}$ washes lowered non-specific absorption on the filters without significant displacement of intracellular ${ }^{45} \mathrm{Ca}^{2+}$. Transport of ${ }^{45} \mathrm{Ca}^{2+}$ was measured at $\mathrm{pH} 8$, in bacteria incubated either in the growth medium or in a Trisbased medium at the required $\mathrm{Na}^{+}$concentration (Trombe et al., 1984).
When the effect of amilorides was examined, these were added to the bacterial suspension before ${ }^{45} \mathrm{Ca}^{2+}$ addition. The initial rate of ${ }^{45} \mathrm{Ca}^{2+}$ transport by DMB-sensitive bacteria was taken as the difference between values obtained in the absence and in the presence of $10 \mu \mathrm{M}-$ DMB.

For $\left[{ }^{14} \mathrm{C}\right]$ isoleucine transport measurements in ATP-depleted bacteria, the same conditions as for fully energized bacteria (Trombe et al., 1984) was used. The initial rates of uptake (determined in the first $15 \mathrm{~s}$ ) were 20-30 times lower than the values obtained in fully energized cells (Trombe et al., 1984).

Calculations were done on the basis that $1 \mathrm{ml}$ of suspension at an $\mathrm{OD}_{550}$ of 1 represents an intracellular free space of $1 \mu \mathrm{l}$ and contains $0.33 \mathrm{mg}$ protein (Trombe et al., 1984).

Genetic analysis. Transformation was used to carry out genetic transfers. The recipient strain was transformed with DNA extracted from the donor under conditions described previously (Trombe $e t$ al., 1992). Selection of transformants was done on plates containing the selective agent. Transformed bacteria for one given marker were tested for a second marker by streaking the colonies on the appropriate selective plates containing either $2 \mu \mathrm{g}$ erythromycin $\mathrm{ml}^{-1}$ or $15 \mu \mathrm{M}$ DMB.

\section{Results}

Evidence for a $D M B$-sensitive $\mathrm{Ca}^{2+}$ transport involved in homeostasis at high $\mathrm{Ca}^{2+}$

When a ${ }^{45} \mathrm{Ca}^{2+}$ gradient $\left(\left[\mathrm{Ca}^{2+}\right]_{\text {out }}>\left[\mathrm{Ca}^{2+}\right]_{\text {in }}\right)$ was imposed on ATP-depleted bacteria (see Methods) a net influx could be measured. At $1.4 \mathrm{~mm}-\mathrm{Ca}^{2+}$, uptake was linear for $30 \mathrm{~s}$ and was followed by efflux with a plateau corresponding to approximately $1 \mathrm{~mm}$ between 3 and 5 min. The $\mathrm{Ca}^{2+}$-channel inhibitor DMB decreased the initial rate of influx and the steady state was not reached (Fig. 1). Initial rates of influx in media containing increasing DMB concentrations showed (Fig. 2a) $50 \%$

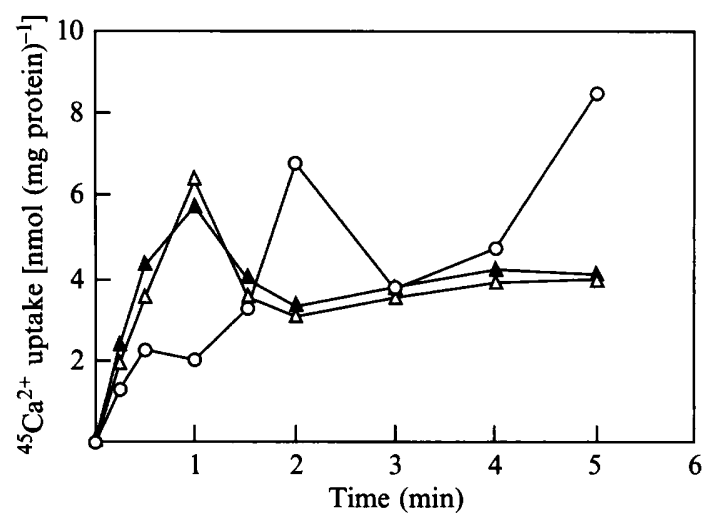

Fig. 1. DMB-sensitive ${ }^{45} \mathrm{Ca}^{2+}$ uptake. Energy-depleted bacteria (intracellular ATP concn $<3 \mu \mathrm{M}$, intracellular $\mathrm{Na}^{2+}$ concn $90 \mathrm{mM}$ ) were suspended in the complex medium, $\mathrm{pH} 7 \cdot 8$, containing $30 \mathrm{~mm}-\mathrm{NaCl}$ and ${ }^{45} \mathrm{Ca}^{2+}(1.2 \mathrm{mM}$, sp. act. $185 \mathrm{fmol} \equiv 1$ c.p.m. $)$ was added. When required, DMB (10 $\mu \mathrm{M}$ final concn) was added to the bacterial suspension before the ${ }^{45} \mathrm{Ca}^{2+}$. At intervals, $0.1 \mathrm{ml}$ samples were filtered and washed (see Methods). The radioactivity of the filters was quantified by liquid scintillation. Calculations were done using the reference data given in Methods. $\triangle, \Delta$, Two independent experiments in DMB-free medium; $O$, uptake in the presence of DMB. 

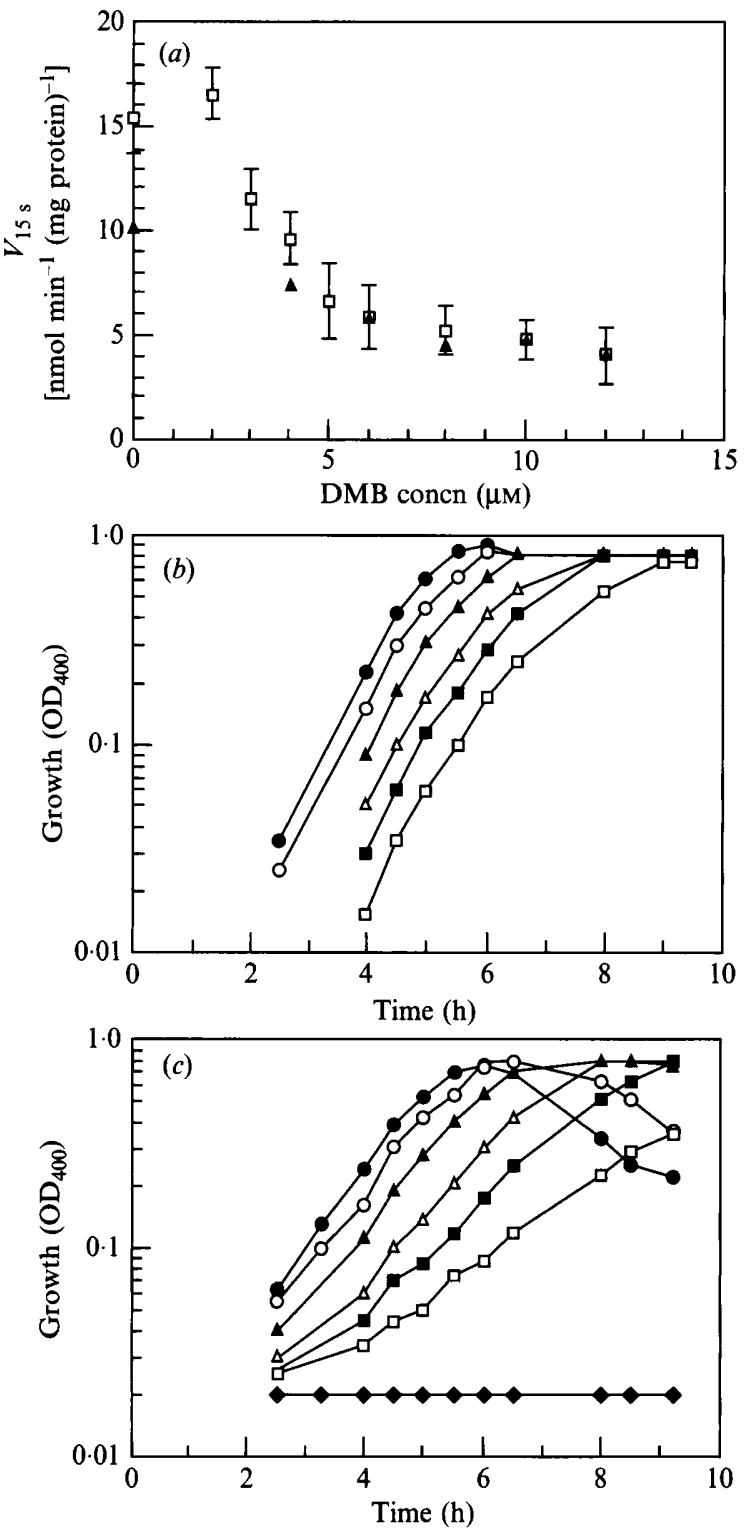

Fig. 2. Inhibition by DMB of $\mathrm{Ca}^{2+}$ transport (a) and growth $(b, c)$. (a) Initial rate of $\mathrm{Ca}^{2+}$ transport $\left(\square,{ }^{45} \mathrm{Ca}^{2+}\right.$ concn $1.2 \mathrm{mM}$, sp. act. $220 \mathrm{fmol}$ $\equiv 1$ c.p.m.; $\Delta,{ }^{45} \mathrm{Ca}^{2+}$ concn $0.4 \mathrm{mM}, 190 \mathrm{fmol} \equiv 1$ c.p.m.) determined in the presence of various concentrations of DMB. The vertical bars represent $\operatorname{SEM}(n=3) .(b, c)$ Growth measurements were made in media containing $0.2 \mathrm{mM}-\mathrm{Ca}^{2+}(b)$ or supplemented with $1 \mathrm{mM}^{-\mathrm{Ca}^{2+}}(c)$ and the following DMB concentrations $(\mu \mathrm{M}): \mathbf{O}, 0 ; \mathrm{O}, 2 ; \boldsymbol{\Delta}, 3 ; \Delta, 4 ; \boldsymbol{\square}$, $5 ; \square, 6 ; \diamond, 10$ ( $c$ only).

inhibition at $4 \mu \mathrm{M}\left(I_{50}\right)$ and a plateau between 8 and $12 \mu \mathrm{M}$. Residual uptake, at the plateau, presumably depends on a DMB-resistant system(s). When added to cultures at high $\mathrm{Ca}^{2+}$, DMB slowed the growth rate, with total inhibition at $10 \mu \mathrm{M}$ (Fig. $2 b$ ), while at low $\mathrm{Ca}^{2+}$, the effect of DMB on bacterial growth related to the duration of the lag phase, rather than the growth rate (Fig. $2 c$ ). Such an effect of $\mathrm{Ca}^{2+}$ on growth-inhibition was not observed in the case of amiloride or its derivative
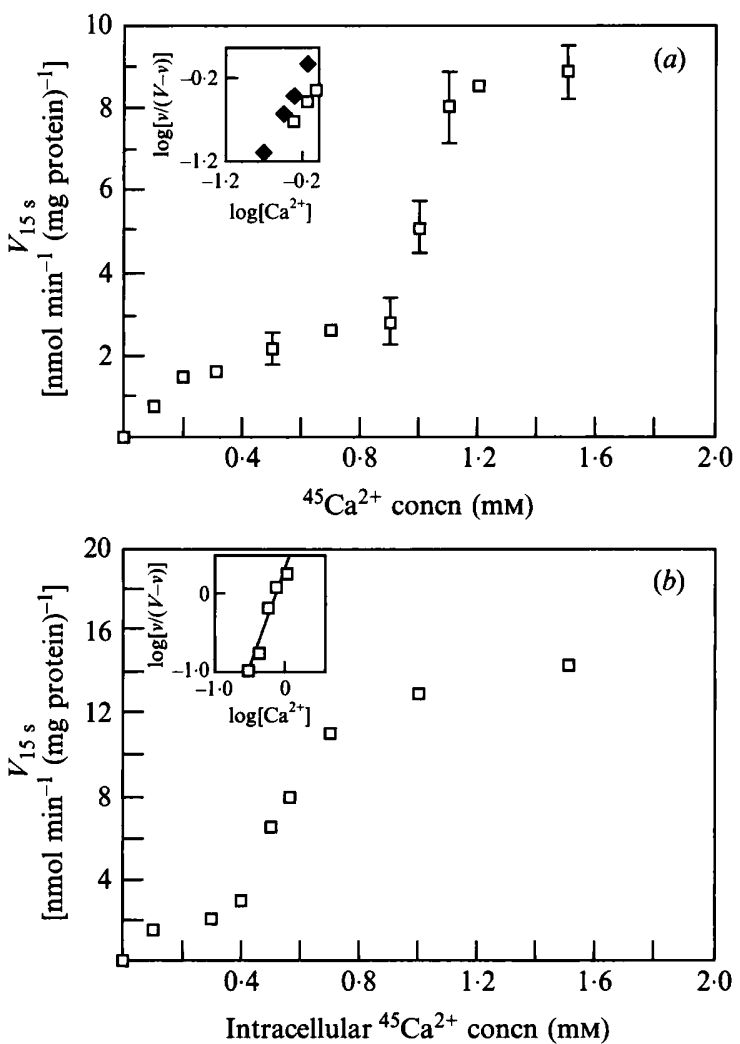

Fig. 3. Kinetics of ${ }^{45} \mathrm{Ca}^{2+}$ influx in response to a $\mathrm{Ca}^{2+}$ gradient $(a)$ and efflux in response to a $\mathrm{Na}^{+}$gradient $(b)$. (a) The initial rate of DMBsensitive ${ }^{45} \mathrm{Ca}^{2+}$ influx as a function of the external $\mathrm{Ca}^{2+}$ concentration was determined as explained in Methods. The inset represents the curve $\log \left[\mathrm{Ca}^{2+}\right]$ versus $\log [v /(V-v)]$ for experiments performed in the complex medium $(\square)$ or in the Tris-based medium $(\bullet)[V$ is the maximal rate at $1.5 \mathrm{~mm}-\mathrm{Ca}^{2+} ; v$ is $V_{15}$ for a given $\mathrm{Ca}^{2+}$ concentration]. The vertical bars represent SEM $(n=3)$. (b) Bacteria from a suspension of $\mathrm{OD}_{550} 5 \cdot 2$ were loaded with various amounts of ${ }^{45} \mathrm{Ca}^{2+}$ by a $4 \mathrm{~min}$ incubation in the Tris-based medium with a $\mathrm{Na}^{+}$concentration $<1 \mathrm{mM}$, containing various concentrations of ${ }^{45} \mathrm{Ca}^{2+}$ at the required specific activity. The radioactivity retained was estimated by filtration of a $0.1 \mathrm{ml}$ aliquot, then a $\mathrm{Na}^{+}$gradient was imposed by addition of $\mathrm{NaCl}$ ( $5 \mathrm{~mm}$ final concn). Samples of $0.1 \mathrm{ml}$ were withdrawn and filtered after 10 and $20 \mathrm{~s}$. Initial rates of efflux were calculated as explained in Methods.

5-( $N, N^{\prime}$-hexamethylene)amiloride (HMA), which did not affect the initial rate of ${ }^{45} \mathrm{Ca}^{2+}$ uptake (data not shown). Altogether, these data point to a DMB-sensitive function involved in $\mathrm{Ca}^{2+}$ circulation. This function is essential for homeostasis in high $\mathrm{Ca}^{2+}$ media.

\section{Kinetics of calcium transport}

A plot showing the initial rate for the DMB-sensitive component of ${ }^{45} \mathrm{Ca}^{2+}$ influx, as a function of the external $\mathrm{Ca}^{2+}$ concentration, exhibits sigmoidicity, with Hill coefficients (nH) of 1.9 (Fig. $3 a$ ). Similar $\mathrm{nH}$ values were obtained from uptake experiments performed in the 


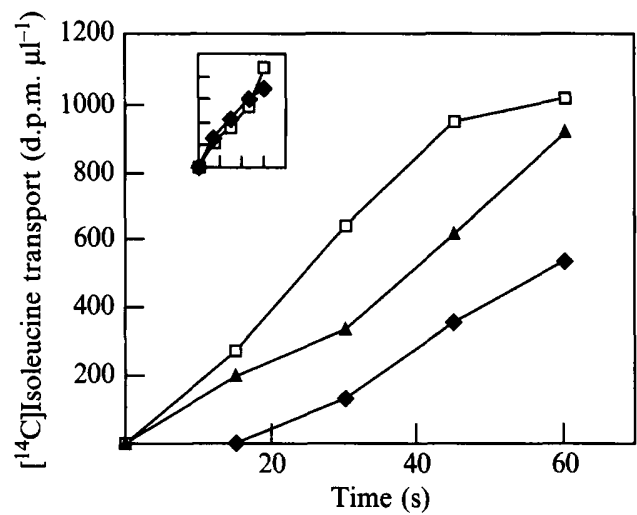

Fig. 4. Effect of $\mathrm{Ca}^{2+}$ on the electrogenic transport of $\left[{ }^{14} \mathrm{C}\right]$ isoleucine. Energy-depleted bacteria were suspended in Tris-based medium at $\mathrm{OD}_{550} 0.3$ and incubated at room temperature in the presence of $\left[{ }^{14} \mathrm{C}\right]$ isoleucine $\left(10^{-2} \mathrm{mM}, 50 \mathrm{fmol} \equiv 1 \mathrm{~d} . \mathrm{p} . \mathrm{m}.\right)$. At intervals, $0.1 \mathrm{ml}$ samples were withdrawn, filtered and rinsed as already described. Results are expressed as d.p.m. per $\mu$ intracellular free space (see Methods). $\square$, Uptake in $\mathrm{Ca}^{2+}$-free medium; $\boldsymbol{\Delta}, \bullet$, simultaneous addition of $\left[{ }^{14} \mathrm{C}\right]$ isoleucine and $1.2 \mathrm{mM}-\mathrm{CaCl}_{2} ;(\boldsymbol{\Lambda}, 10 \mu \mathrm{M}-\mathrm{DMB}$ was added to the suspension before $\left[{ }^{14} \mathrm{C}\right]$ isoleucine and $\left.\mathrm{CaCl}_{2}\right)$. Inset, $\left[{ }^{14} \mathrm{C}\right]$ isoleucine transport in a $\mathrm{Ca}^{2+}$ free medium, in the absence $(\diamond)$ or in the presence ( $\square$ ) of $10 \mu \mathrm{M}-\mathrm{DMB}$. The scale in the inset is the same as in the main figure. The initial rate of transport in $\mathrm{Ca}^{2+}$-free medium

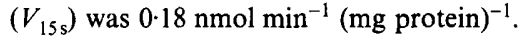

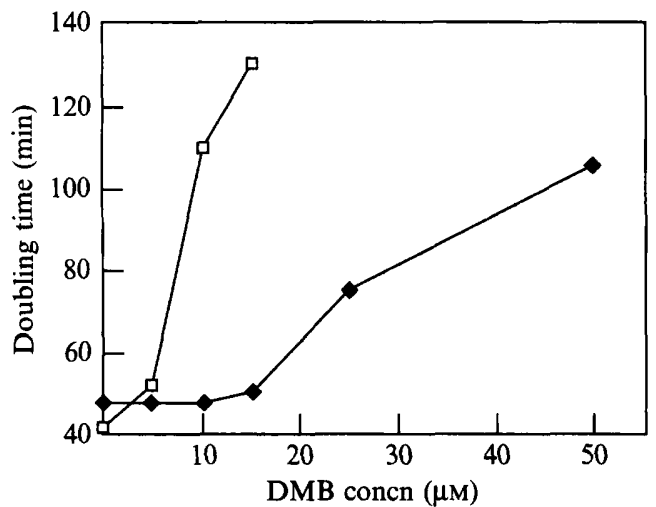

Fig. 5. Effect of DMB on the growth rate of the wild-type ( $\square$ ) and mutant $\mathrm{Cp} 2200(\checkmark)$ in high-Ca ${ }^{2+}$ medium. Doubling times of cultures growing in high-Ca ${ }^{2+}$ medium containing various concentrations of $\mathrm{DMB}$ were determined on growth curves between $\mathrm{OD}_{400} 0 \cdot 1$ and $0 \cdot 2$.

complex medium or in a Tris-buffered medium (Fig. $3 a$, inset). When bacteria were preloaded to obtain internal $\mathrm{Ca}^{2+}$ concentrations ranging from 0.3 to $1.5 \mathrm{mM}$, efflux could be triggered by shifting the $\mathrm{NaCl}$ concentration of the medium to $5 \mathrm{~mm}$. The initial rates of ${ }^{45} \mathrm{Ca}^{2+}$ efflux as a function of the intracellular $\mathrm{Ca}^{2+}$ concentration were also sigmoidal, with an $\mathrm{nH}$ value of 1.7 (Fig. $3 b$ ). It is likely that this cooperativity represents an intrinsic property of the transporter functioning as a $\mathrm{Na}^{+} / \mathrm{Ca}^{2+}$ exchanger.

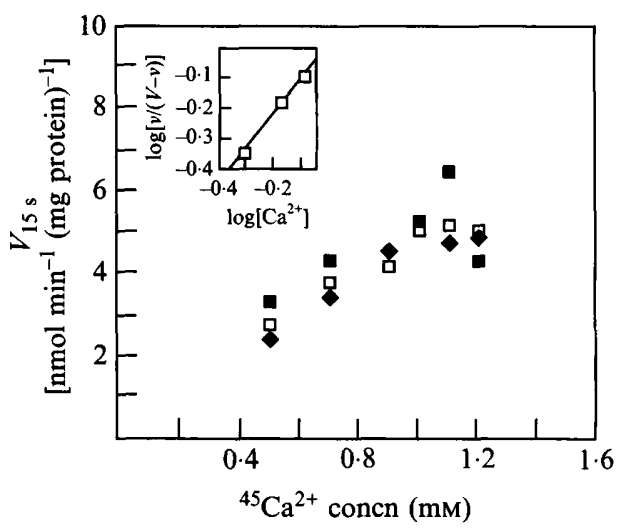

Fig. 6. Kinetics of ${ }^{45} \mathrm{Ca}^{2+}$ influx in strain $\mathrm{Cp} 2200$. The experiment was performed as described in legend of Fig. 3(a). The $\mathrm{OD}_{550}$ of the bacterial suspension was $5 \cdot 4$. The values obtained by three measurements of the initial rate of influx for a given ${ }^{45} \mathrm{Ca}^{2+}$ concentration are plotted. For Hill plots (inset) the mean values were taken.

\section{Electrogenicity of transport}

Electrogenicity of $\mathrm{Ca}^{2+}$ influx was checked using the electrogenic uptake of isoleucine as a probe (Trombe et al., 1984; Trombe, 1984). Inhibition of isoleucine uptake by $\mathrm{Ca}^{2+}$ influx should reflect membrane depolarization. Addition of $\mathrm{Ca}^{2+}$ to the uptake medium abolished $\left[{ }^{14} \mathrm{C}\right]$ isoleucine uptake after $15 \mathrm{~s}$ (Fig. 4.) This delay corresponds to the kinetics of $\mathrm{Ca}^{2+}$ influx (Fig. 1). DMB suppressed the $\mathrm{Ca}^{2+}$ effect. In a $\mathrm{Ca}^{2+}$-free medium, DMB $(10 \mu \mathrm{M})$ did not alter the rate of isoleucine transport (Fig. 4 , inset). This suggests that $\mathrm{Ca}^{2+}$ inhibition of isoleucine uptake is due to electrogenic $\mathrm{Ca}^{2+}$ influx, via the DMBsensitive porter.

Genetic correlation between $\mathrm{Ca}^{2+}$ transport, growth, competence induction and autolysis

Among spontaneous mutants resistant to $15 \mu \mathrm{M}-\mathrm{DMB}$ $\left(\mathrm{DMB}^{\mathrm{R}}\right)$, clone $\mathrm{DMB}^{\mathrm{R} 1}$ was chosen because it showed a reduced rate of ${ }^{45} \mathrm{Ca}^{2+}$ transport. Mutant $\mathrm{CP} 2200$ was constructed by transformation of the wild-type strain Cp1015 with DNA from mutant $\mathrm{DMB}^{\mathrm{R} 1}$ and its growth inhibition by DMB was verified (Fig. 5). The uptake kinetics of ${ }^{45} \mathrm{Ca}^{2+}$ showed a lower cooperativity than the wild-type strain, $\mathrm{nH}=1.3$ (Fig. 6). This mutant did not develop natural competence in high- $\mathrm{Ca}^{2+}$ medium (20 independent experiments) and was resistant to autolysis. This provides genetic evidence to implicate the kinetics of $\mathrm{Ca}^{2+}$ transport in the $\mathrm{Ca}^{2+}$ response. Interestingly, resistance to autolysis and the loss of natural transformability in mutant Cp2200 are reminiscent of the characteristics of the competence-defective $\left(\mathrm{Com}^{-}\right)$mutant Cp1322 (Morrison et al., 1984; Trombe et al., 1992); however, strain $\mathrm{Cp} 1322$, selected for its defect in natural transformability, was not DMB-resistant. Genetic 
analysis was performed to determine whether the gene conferring the $\mathrm{DMB}^{\mathrm{R} 1}$ phenotype, carried by DNA of strain CP2200, and comA::ermAM, carried by the recipient strain Cp1322 (Ery $\left.{ }^{R}\right)$, were alleles. No Ery transformant was found among $100 \mathrm{DMB}^{\mathrm{R}}$ transformants after transformation of strain Cp1322 by DNA extracted from mutant $\mathrm{Cp} 2200$, suggesting that these markers were not carried by the same DNA transforming molecule. The average size of a transforming molecule being estimated around $5 \mathrm{~kb}$, it is likely that the mutation responsible for the $\mathrm{DMB}^{\mathrm{R} 1}$ phenotype defines a new gene which regulates the $\mathrm{Ca}^{2+}$ response, including competenece induction.

\section{Discussion}

Kinetic analysis of ${ }^{45} \mathrm{Ca}^{2+}$ transport in ATP-depleted $S$. pneumoniae provides evidence for $\mathrm{Ca}^{2+}$ transport down its electrochemical potential Figs $1,3 a$ ) and in response to an imposed $\mathrm{Na}^{+}$gradient (Fig. $3 b$ ). This transport is sensitive to the amiloride derivative DMB (Figs 1, 2a). Neither amiloride itself nor HMA inhibited the initial rate of ${ }^{45} \mathrm{Ca}^{2+}$ transport. Thus $S$. pneumoniae probably possesses a DMB-sensitive $\mathrm{Na}^{+} / \mathrm{Ca}^{2+}$ antiporter. Using electrogenic isoleucine transport (Trombe et al., 1984) as a reporter activity, it was shown that the DMB-sensitive component of the $\mathrm{Ca}^{2+}$ transport was electrogenic (Fig. 4). In prokaryotes, electrogenic $\mathrm{Ca}^{2+}$ transport has already been described for several species (Tsujibo \& Rosen 1983; Vrij et al., 1985), and observed in ATPdepleted Streptococcus faecalis (Kobayashi et al., 1978). However, no specific inhibitor was characterized. In $S$. pneumoniae, DMB defines a function which probably corresponds to a $\mathrm{Na}^{+} / \mathrm{Ca}^{2+}$ antiporter essential for growth at high $\mathrm{Ca}^{2+}$ concentrations. The DMB concentration $(10 \mu \mathrm{M})$ at which the plateau of uptakeinhibition is observed, suggesting a total block of the porter (Fig. 2a), corresponds to total inhibition of growth at high $\mathrm{Ca}^{2+}$ (Fig. $2 c$ ). The most likely hypothesis is that, in vivo, the porter mediates both influx and efflux of $\mathrm{Ca}^{2+}$ by antiport of $\mathrm{Na}^{+}$and thus adjusts the intracellular $\mathrm{Ca}^{2+}$ concentration to a level compatible with growth.

On the other hand, the DMB concentration that lowers by $50 \%$ the rate of transport $\left(I_{50}=4 \mu \mathrm{M}\right)$ (Fig. $2 a$ ) corresponds to the inhibitory concentration for competence induction and for autolysis (Trombe et al., 1992; Fig. 2b). Finally, the reduced value for the initial rate of $\mathrm{Ca}^{2+}$ transport at high $\mathrm{Ca}^{2+}$ in mutant $\mathrm{Cp} 2200$ due to a loss of cooperativity (Fig. 6) can be correlated with a deficiency in natural competence and with resistance to autolysis. This shows that the initial rate of $\mathrm{Ca}^{2+}$ uptake via the DMB-sensitive porter is involved in the regulation of competence and of autolysis (Trombe et al., 1992).
It is noteworthy that in the wild-type strain, cooperativity of transport has an $\mathrm{nH}$ value of 2 for influx and efflux (Fig. 3a,b). Indeed, the $\mathrm{Ca}^{2+}$ concentration of $1 \mathrm{mM}$, where the inflexion point is observed in kinetics studies, falls in the same order of magnitude as the critical concentration at which the $\mathrm{Ca}^{2+}$ response is induced (Trombe et al., 1992) and corresponds to the $\mathrm{Ca}^{2+}$ concentration of body fluids that constitute the natural habitat of $S$. pneumoniae. Considering the transport kinetics, in this range of values tiny changes in $\mathrm{Ca}^{2+}$ concentration should result in large shifts of the rate of transport. This constitutes a valuable property for a putative sensor of $\mathrm{Ca}^{2+}$ concentration in the medium or in the cytoplasm.

The consequences of growth at high $\mathrm{Ca}^{2+}$ characterized to date are autolysis activation and competence induction (Trombe et al., 1992). Indeed, competence has been associated with cytoplasmic alkalinization, stimulation of glycolysis (Lopez et al., 1989), induction of specific oligopeptides (Morrison \& Baker, 1979), activation of a membrane endonuclease (Lacks et al., 1975; Puyet et al., 1990) and DNA transport activity (Clavé et al., 1987; Clavé \& Trombe, 1989). Thus competence might be considered as a 'specialized' physiological state associated with ionic signals and triggered by $\mathrm{Ca}^{2+}$ influx. Such a description of competence does not exist for other systems such as Bacillus subtilis, where the cascade of gene regulation implicated in the onset of competence is well established (Dubnau, 1991).

Amiloride-sensitive ion channels have been extensively described in eukaryotes (Cuthbert \& Fanelli, 1978; Kaczorowski et al., 1985; Simchowitz \& Cragoe, 1986). $\mathrm{Na}^{+}$circulation, through an amiloride-sensitive $\mathrm{Na}^{+} / \mathrm{H}^{+}$ antiporter, appears to be a critical event in generating ionic signals. These signals are represented by an increase in cytoplasmic $\mathrm{pH}$ and $\mathrm{Na}^{+}$(Paris \& Pouyssegur, 1983; Pouyssegur et al., 1984). These signals, associated with an elevation of free cytoplasmic $\mathrm{Ca}^{2+}$, are ubiquitous in the response of eukaryotic cells to growth factors and hormones (for reviews, see Rozengurt, 1980; Metcalfe $e t$ $a l ., 1985)$. On the other hand, it has been proposed that $\mathrm{Ca}^{2+}$ uptake is the determining step in cell differentiation and hence in the cell cycle (Miyakama et al., 1985; Iida et al., 1990).

The $\mathrm{Ca}^{2+}$ effect in S. pneumoniae is controlled by an exported protein (Trombe et al., 1992) named competence factor (CF) (Tomasz \& Hotchkiss, 1964). CF probably recognizes a specific receptor on the cytoplasmic membrane (Ziegler \& Tomasz, 1970). It has been shown that $\mathrm{CF}$ stimulates a DMB-sensitive ${ }^{45} \mathrm{Ca}^{2+}$ influx but does not lower the $\mathrm{Ca}^{2+}$ requirement for competence induction (Trombe et al., 1992). It is proposed that CF activation of the $\mathrm{Ca}^{2+}$ response occurs through the stimulation of $\mathrm{Ca}^{2+}$ influx via the DMB-sensitive porter. 
The cooperativity level, as regards $\mathrm{Ca}^{2+}$, that modulates the rate of cation uptake might constitute the critical parameter where regulation occurs. The behaviour of strain Cp2200, which carries a pleiotropic mutation that lowers cooperativity of $\mathrm{Ca}^{2+}$ transport and alters the regulation of competence and of autolysis, appears to fit this hypothesis. Other mutants showing an enhanced $\mathrm{nH}$ value for $\mathrm{Ca}^{2+}$ transport have been isolated and are now being studied.

I thank Dr J. Pouyssegur for encouragement, precious discussions and valuable suggestions during the course of this work, and Dr G. Lanéelle and Dr. N. Lindley for critical reading of the manuscript. ATP measurements were performed by S. Wagner and lysis kinetics were determined by Veronique Rieux. Both were graduate students. This work was supported by CNRS, L.P. 008201 and Université Paul Sabatier, Toulouse, France.

\section{References}

Ambudkar, S. V., Lynn, A. R., Maloney, P. C. \& Rosen, B. P. (1986). Reconstitution of ATP-dependent calcium transport from streptococci. Journal of Biological Chemistry 261, 15596-15600.

Berry, A. M., Lock, R. A., Hansman, D. \& Paton, J. C., (1989). Contribution of autolysin to virulence of Streptococcus pneumoniae. Infection and Immunity 57, 2324-2330.

CAMPBell, A. K. (1983). Intracellular Calcium: its Universal Role as Regulator. Chichester: John Wiley.

CARAFOLI, D. (1987). Intracellular calcium homeostasis. Annual Review of Biochemistry 57, 395, 395-433.

CARAFOl, E. (1988). The intracellular homeostasis of calcium: an overview. Annals of the New York Academy of Sciences. 551, $147-158$.

Cegielska, A. \& Georgopoulos, C. (1989). Functional domains of the Escherichia coli dnaK heat shock protein as revealed by mutational analysis. Journal of Biological Chemistry 264, 21122-21130.

Clavé, C., Morrison, D. A. \& Trombe, M. C. (1987). Is DNA transport driven by the proton electrochemical potential difference in naturally transformable Streptococcus pneumonia? Bioelectrochemistry and Bioenergetics 17, 269-276.

Clavé, C. \& Trombe, M. C. (1989). Intracellular pH and ATP involvement in DNA uptake by Streptococcus pneumoniae. FEMS Microbiology Letters 65, 113-118.

Cuthrert, A. W. \& Fanelly, G. M. (1978). Effects of some pyrazinecarboxamides on sodium transport in frog skin. Journal of Pharmacology. 63, 139-149.

DubNaU, D. (1991). Genetic competence in Bacillus subtilis. Microbiological Reviews. 55, 395-424.

Falah, A. M. S., Bathnagar, R., Bathnagar, N., Singh, Y., Sidhu, G. S., Murthy, P. S. \& Venkitasubramanian, T. A. (1988). On the presence of calmodulin-like protein in mycobacteria. FEMS Microbiology Letters 56, 89-94.

FREY, J. \& NiCOLET, J. (1988). Regulation of hemolysin expression in Actinobacillus pleuropneumoniae serotype 1 and $\mathrm{Ca}^{2+}$. Infection and Immunity 56, 2570-2575.

Fry, I. J., Villa, L., Kuehn, G. D. \& Hageman, J. H. (1983). Calmodulin-like protein from Bacillus subtilis. Biochemical and Biophysical Research Communications 134, 212-217.

HefFNER, D. L. (1982). Transport of $\mathrm{H}^{+}, \mathrm{K}^{+}, \mathrm{Na}^{+}$and $\mathrm{Ca}^{2+}$ in Streptococcus. Molecular and Cellular Biochemistry 44, 81-106.

Iada, H., SaKaguchi, S., Yagava, Y. \& ANRakU, Y. (1990). Cell cycle control by $\mathrm{Ca}^{2+}$ in Saccharomyces cerevisiae. Journal of Biological Chemistry 265, 21216-21222.

InouYe, S., Franceschini, T. \& Inouye, M. (1983). Structural similarities between the development-specific protein $\mathrm{S}$ from a Gramnegative bacterium Myxococcus xanthus and calmodulin. Proceedings of the National Academy of Sciences of United State of America 80, 6829-6833.
Kaczorowski, G. J., Barros, F., Dethmers, J. K. \& Trumble, M. J. (1985). Inhibition of $\mathrm{Na}^{2+} / \mathrm{Ca}^{2+}$ exchange in pituitary membrane vesicles by analogues of amilorides. Biochemistry 24, 1394-1403.

Kobayashi, H., Van Brunt, J. \& Harold, F. M. (1978). ATP-linked calcium transport in cells and membrane vesicles of Streptococcus faecalis. Journal of Biological Chemistry 253, 2085-2092.

LACKS, S. A., GreENBERG, B. \& NeUberger, M. (1975). Identification of a deoxyribonuclease implicated in genetic transformation of Diplococcus pneumoniae. Journal of Bacteriology 123, 222-232.

lopez, A., Clavé, C., Capeyrou, R., Lafontan, V. \& Trombe, M. C. (1989). Ionic and energetic changes at competence in the naturally transformable bacterium Streptococcus pneumoniae. Journal of General Microbiology 135, 2189-2197.

Metcalfe, J. C., Hesketh, T. R., Smith, G. A., Morris, D. H., Corps, A. N. \& MoORE, J. P. (1985). Early response pattern analysis of the mitogenic pathway in lymphocytes and fibroblasts. Journal of Cell Sciences (Suppl.) 3, 199-228.

Mryakama, T., Tachikawa, T., Jeong, Y. K., Tsushiya, E. \& Fukui, S. (1985). Transient increase of $\mathrm{Ca}^{2+}$ uptake as a signal of mating pheromone-induced differentiation in the heterobasidiomycetous yeast Rhodospiridium toruloides. Journal of Bacteriology 162, 1304-1306.

Morrison, D. A. \& BaKer, F. M. (1979). Competence for genetic transformation in pneumococcus depends on the synthesis of a small set of proteins. Nature, London 282, 215-217.

Morrison, D. A., Trombe, M. C., Hayden, M. K., WaszaCK, G. A. \& CHEN, J. D. (1984). Isolation of transformation-deficient Streptococcus pneumoniae mutants defective in control of competence, using insertion-duplication mutagenesis with the erythromycine resistance determinant pAMB1. Journal of Bacteriology 159, 870-876.

Norris, V., Chen, M., Goldberg, M., Voskuil, J., McGurk, G. \& Holland, B. (1991). Calcium in bacteria: a solution to which problem? Molecular Microbiology 5, 775-778.

ONEK, L. A. \& SMITH, R. J. (1992). Calmodulin and calcium mediated regulation in prokaryotes. Journal of General Microbiology 138, 1039-1049.

Paris, S. \& Pouyssegur, J. (1984). Growth factors activate the $\mathrm{Na}^{+} / \mathrm{H}^{+}$antiporter in quiescent fibroblasts by increasing its affinity for intracellular $\mathrm{H}^{+}$. Journal of Biological Chemistry 259, 10989-10994.

Pouyssegur, J., Sardet, C., Franchi, A., L'Allemain, G. \& Paris, S. (1984). A specific mutation abolishing $\mathrm{Na}^{2+} / \mathrm{H}^{+}$antiport activity in hamster fibroblasts precludes growth at neutral and acidic $\mathrm{pH}$. Proceedings of the National Academy of Sciences of the United States of America 81, 4833-4837.

Puyet, A., Greenberg, B. \& Lacks, S. A. (1990). Genetic and structural characterization of EndA, a membrane-bound nuclease required for transformation of Streptococcus pneumoniae. Journal of Molecular Biology 213, 727-738.

Rosen, B. P. (1987). Bacterial calcium transport. Biochimica et Biophysica Acta 906, 101-110.

RozenGURT, E. (1980). Stimulation of DNA synthesis in quiescent cultured cells: exogenous agents, internal signals, and early events, Current Topics in Cellular Regulation 17, 59-88.

Sanchez-Puelles, J. M., Ronda, C., Garcia, J. L., Garcia, P., LOPEZ, R. \& GARCIA, E. (1986). Searching for autolysin functions. Characterization of a pneumococcal mutant deleted in the lyt $A$ gene. European Journal of Biochemistry 158, 289-293.

Simchovitz, L. \& Cragoe, E. J. (1986). Inhibition of chemotactic factor-activated $\mathrm{Na}^{+} / \mathrm{H}^{+}$exchange in human neutrophils by analogs of amilorides: structure-activity relationships in the amiloride series. Molecular Pharmacology 30, 112-120.

Swan, D. G., Hale, R. S., Dillon, N. \& Leadley, P. F. (1987). A bacterial calcium-binding protein homologous to calmodulin. Nature, London 329, 84-89.

Swan, D. G., Cortes, J., Hales, R. S. \& Leadley, P. F. (1989). Cloning, characterization and heterologous expression of the Saccharopolyspora erythraea gene encoding an EF-Hand calciumbinding protein. Journal of Bacteriology 171, 5614-5619.

TIRABY, G. \& FoX, M. (1973). Marker discrimination in transformation and mutation of Streptococcus pneumoniae. Proceedings of the 
National Academy of Sciences of the United States of America 70, 3541-3545.

Tomasz, A. \& Hotchкiss, R. D. (1964). Regulation of the transformability of pneumococcal cultures by macromolecular cells products. Proceedings of the National Academy of Sciences of the United States of America 51, 480-487.

Trombe, M. C. (1984). Alteration of Streptococcus pneumoniae membrane properties by the folate analog methotrexate. Journal of Bacteriology 160, 2840-2853.

Trombe, M. C., Lanéelle, G. \& Sicard, A. M. (1984). Characterization of a Streptococcus pneumoniae mutant with altered electric transmembrane potential. Journal of Bacteriology 158, 1109-1114.
Trombe, M. C., Clavé, C. \& Manias, J. M. (1992). Calcium regulation of growth and differentiation in Streptococcus pneumoniae. Journal of General Microbiology 138, 77-84.

TSuJiBo, H. \& Rosen, B. (1983). Energetics of calcium efflux from cells of Eschericia coli. Journal of Bacteriology 154, 854-858.

VriJ, W., Bulthuis, R., Postma, E. \& Konings, W. M. (1985). Calcium transport in membrane vesicles of Bacillus subtilis. Journal of Bacteriology 164, 1294-1300.

ZIEGLER, R. \& TOMASZ, A. (1970). Binding of competence factor to receptors in the spheroplast membrane of streptococci. Biochemical and Biophysical Research Communications 41, 1342-1349. 